\author{
Research Article
}

\title{
A CLINICAL COMPARATIVE STUDY ON THE EFFICACY OF SAHACHARADI KWATH WITH AND WITHOUT MATRA BASTI IN THE MANAGEMENT OF JANU SANDHIGAT VATA W.S.R. TO OSTEO ARTHRITIS
}

\section{Hetal Ramani1, Akanksha Sharma2*, Dhaval Movaliya ${ }^{3}$, Sweety Ruparel ${ }^{4}$}

${ }^{1}$ Assistant Professor., Department of Panchkarma, Shree BG Garaiya Ayurveda college, Rajkot, Gujrat.

${ }^{*}$ Ayurvedic Medical Officer (M.D Panchakarma) at Department of Ayush Govt. of J\&K.

${ }^{3}$ Assistant Professor., Department of Shalyatantra, Shree BG Garaiya Ayurveda College, Rajkot, Gujrat.

${ }^{4}$ Principal and HOD Department of Panchakarma, State Model College of Ayurveda, Kolavada, Gandhinagar, Gujrat, India.

\begin{tabular}{l} 
Article info \\
\hline Article History: \\
Received: 28-11-2021 \\
Revised: $16-12-2021$ \\
Accepted: 12-01-2022 \\
\hline KEYWORDS: \\
Sandhigata Vata, \\
Matra Basti, \\
Sahacharadi Kwath \\
Til Taila.
\end{tabular}

ABSTRACT
Sandhigat Vata is a Vata vyadhi of degenerative nature, and Basti is preferred line of treatment
for all Vata vyadhi as mentioned by Acharya Charak. Matra Basti is a type of Anuvasan Basti
which is used for many degenerative diseases. So for present study Matra Basti with Sahachar
Tail was selected. Acharya Charaka has mentioned Sahachar Taila in the management of the
Vat Vyadhi. Acharya Yogratnakar has mentioned Sahacharadi Kwath with Til Taila under the
context of Vat Vyadhi. Here Sahacharadi Kwath with Til Taila was selected for Shaman Chikitsa.
Aims and objectives: To evaluate and compare the effect of Sahacharadi Kwath with and
without Matra Basti in the management of Janu Sandhigat Vata w.s.r to Osteo-arthritis.
Material and methods: For present study 30 patients of Janu Sandhigat Vata were selected
according to the classical signs and symptoms of Sandhigat Vata according to Ayurveda as well
as modern science, were randomly divided into 2 . Result: In Group A, total 15 patients were
treated. Out of 15 patients $20.0 \%$ patients got marked improvement, $73.33 \%$ got moderate
improvement while $6.67 \%$ patients got mild improvement. No patient got complete remission.
In Group B, total 15 patients were treated. Out of them $6.67 \%$ patients got marked
improvement, $40.0 \%$ patients got moderate improvement and $46.67 \%$ showed mild
improvement. One patient remains unimproved. No patient got complete remission.
Conclusion: It is concluded that Matra Basti along with Sahacharadi Kwath provided better
result as compare to only Sahacharadi Kwath in the management of Janu Sandhigata Vata.

\section{INTRODUCTION}

In Vridhdhavastha Vata Dosha is in a dominant state and Rasadi Dhatus are in a deprived state. This potent combination is responsible for the aged being vulnerable to many diseases. Among them, Sandhigata Vata is one of them. When Vata Dosha is vitiated and accumulates in Sandhi (joint), it is called Sandhigat Vata. It is a disease of Sandhi (joint) with symptoms of Sandhishula, Sandhishotha, Akunchan Prasarnjany Vedana, Sandhigrah, Sandhi Sphutna ${ }^{[1]}$ etc.

\begin{tabular}{|l|l|}
\hline \multicolumn{3}{|c|}{ Access this article online } \\
\hline Quick Response Code & \begin{tabular}{l} 
https://doi.org/10.47070/ijapr.v10i1.2242 \\
\hline
\end{tabular} \\
\cline { 2 - 3 } & $\begin{array}{l}\text { Published by Mahadev Publications (Regd.) } \\
\text { publication licensed under a Creative } \\
\text { Commons Attribution-NonCommercial- } \\
\text { ShareAlike 4.0 International (CC BY-NC-SA 4.0) }\end{array}$ \\
\hline
\end{tabular}

The condition is much similar with osteoarthritis in modern medical science. Osteoarthritis is a degenerative joint disorder characterized by degeneration of joint cartilage and adjacent bones that can cause joint pain and stiffness. This is one of such disease commonly affecting a large number of elderly individuals. It clinically presents as joint pain, swelling over the joint, difficulty walking, tenderness and crepitus in the elderly age group. OA stands top in the list of geriatric diseases.

Sandhigat Vata is a Vata vyadhi of degenerative nature, and Basti is preferred line of treatment for all Vata vyadhi as mentioned by Acharya Charak. Matra Basti is a type of Anuvasan Basti which is used for many degenerative diseases. By Matra Basti we achieve good result without following strict regime. So for present study Matra Basti with Sahachar Taila was selected. Acharya Charaka has mentioned Sahachar 
Taila in the management of the Vata Vyadhi. Acharya Yogratnakar has mentioned Sahacharadi Kwath with Til Taila under the context of Vat Vyadhi[2]. Here Sahacharadi Kwath was selected for Shaman Chikitsa.

The study was conducted on 30 clinically diagnosed and confirmed patients of Janu Sandhigatvata. The study was randomly divided into 2 Groups. 15 patients were treated in each group. Group A was given Matra Basti (Sahchar Taila)[3] for 15 days along with Sahcharadi Kwath with Til Taila orally for 4 weeks while Group B was given Sahcharadi Kwath with Til Taila orally for 4 weeks.

\section{AIMS AND OBJECTIVES}

To evaluate and compare the effect of Sahacharadi Kwath with and without Matra Basti in the management of Janu Sandhigat Vata w.s.r to Osteoarthritis.

\section{Ethical Clearance}

Study was started after obtaining Ethical clearance from Institutional Ethical Committee, Vide Certi. No.68 dated 13/07/2016. Govt. Akhandanand Ayurvedic College, Ahmedabad.

\section{CTRI Registration}

This clinical trial is registered under CTRI (Clinical Trials Registry of India) with CTRI no CTRI/2017/12/ 010883.

\section{MATERIAL AND METHODS}

\section{Criteria for Selection of Patients}

Patients of Janu Sandhigat Vata were selected according to the classical signs and symptoms of Sandhigat Vata according to Ayurveda like Sandhishula, Sandhishotha, Akunchan prasarne vedana etc. as well as modern science like pain in knee, swelling over it, difficulty in walking etc., were randomly divided into 2 groups irrespective of age, sex, caste, religion, profession etc., from the OPD \& IPD of Govt. Akhandanand Ayurved Hospital.

\section{Inclusion Criteria}

For clinical study, patients having classical signs and symptoms of Janu Sandhigat Vata were selected from the OPD and IPD of Govt. Akhandanand Ayurveda hospital, Ahmedabad.

\section{> Matra Basti Yogya}

$>$ Patients presenting with the classical signs and symptoms of Sandhi Vata (OA) like Sandhishula, Sandhishotha, Akunchan prasarne vedana etc.

$>$ Patients of either sex age between 40-70 years were included.

\section{Exclusion Criteria}

$>$ Matra Basti Ayogya

$>$ Patients below 40 years and above 70 years of age.

$>$ Patients suffering from Vatarakta, Amavata, Systemic Lupus Erythematous (SLE), bone TB, diabetes, psoriatic arthritis and other serious systemic disorders were excluded.

\section{Diagnostic Criteria}

Patients having classical signs and symptoms of the Sandhigat Vata according to Ayurveda as well as modern science were taken into consideration.

\section{Investigations}

Haematological Examination: HB\%, TLC, DLC, ESRTo rule out other pathologies.

Urine Examinations: Routine and Microscopic- To rule out other pathologies.

Radiological Assessment: Plain X-Ray AP and lateral view. (For diagnostic purpose)

\section{Informed Consent}

Written consent of the patient was taken before starting the intervention.

\section{Design of Group and Management}

Study Design: The research study was designed of Open ended parallel clinical trial with Random sampling method. After diagnosis patients were categorized into two groups i.e., Group A \& Group B.

Group A: Total 15 Basti were administered to each patient in the course of Matra Basti. Simultaneously patients were also given Sahacharadi Kwath orally for 4 weeks.

\section{Matra Basti}

>15 Matra Basti were administered to each patient.

$>$ Drug \& Dose: Sahachar Taila, 60ml

$>$ Basti pradan kal: Immediately after meal (at noon)

\section{Shaman}

Simultaneously patients were also given Sahacharadi Kwath orally for 4 weeks.

> Drugs \& Dose: Sahcharadi Kwath, $40 \mathrm{ml}$ twice a day with $5 \mathrm{ml}$ Til Taila.

$>$ Time \& Duration: At morning and evening empty stomach for 4 weeks.

Group B: Patients were treated only with Sahcharadi kwath orally with Til Taila for 4 weeks.

\section{Follow Up}

After completion of the treatment, patient was advised to visit weekly for follow up for 4 weeks.

\section{Statistical Analysis}

The information gathered on the basis of above observations was subjected to statistical analysis. The Paired t-Test has been carried out for all data to analyze the effect of individual therapy in the both groups. Unpaired t-Test has been used to compare the effect of therapies of the two groups all data. The obtained results have been interpreted as: insignificant $\mathrm{P}>0.05$, significant $\mathrm{P}<0.05$, highly significant $\mathrm{P}<0.001$. 


\section{Criteria for Assessment}

The indoor patients were examined daily and outdoor patients weekly. Change was observed in signs and symptoms by using proper clinical methods before and after treatment. The detail of score given to each sign and symptom and clinical test carried out is described below.

\section{Gradation for Sandhi Shula}

\begin{tabular}{|l|l|}
\hline No pain & 0 \\
\hline Mild pain & 1 \\
\hline Moderate pain but no difficulty in walking & 2 \\
\hline Slight difficulty in moving & 3 \\
\hline Severe difficulty in walking/ Unable to walk & 4 \\
\hline
\end{tabular}

Gradation for Sandhigrah (Joint Stiffness)

\begin{tabular}{|l|l|}
\hline Normal flexion/No stiffness & 0 \\
\hline Mild restriction & 1 \\
\hline Moderate restriction & 2 \\
\hline Severe restriction & 3 \\
\hline
\end{tabular}

\section{Gradation for tenderness}

\begin{tabular}{|l|c|}
\hline No tenderness & 0 \\
\hline Patient complains of pain & 1 \\
\hline Patient complains of pain and winces & 2 \\
\hline Patient withdrawal joint on touch & 3 \\
\hline Patient doesn't allow to touch the joint & 4 \\
\hline
\end{tabular}

\section{Gradation for Sandhi Shotha/ Swelling}

\begin{tabular}{|l|c|}
\hline No swelling & 0 \\
\hline Mild swelling & 1 \\
\hline Moderate swelling & 2 \\
\hline Severe swelling & 3 \\
\hline
\end{tabular}

\section{OBSERVATION}

Demographic Profile of the Subject

Table 1: Distribution of 30 Patients according to Age

\begin{tabular}{|c|l|c|c|c|c|}
\hline \multirow{2}{*}{ S. No. } & \multirow{2}{*}{ Age(In Yrs) } & \multicolumn{2}{|c|}{ No. of Patients } & \multirow{2}{*}{ Total } & \multirow{2}{*}{$\%$} \\
\cline { 2 - 5 } & & Group A & Group B & & 40 \\
\hline 1. & $40-50$ & 5 & 7 & 12 & 30 \\
\hline 2. & $51-60$ & 3 & 6 & 9 & 30 \\
\hline 3. & $61-70$ & 7 & 2 & 9 & $\mathbf{1 0 0} \%$ \\
\hline
\end{tabular}

Table 2: Distribution of 30 Patients according to Occupation

\begin{tabular}{|c|l|c|c|c|c|}
\hline \multirow{2}{*}{ S. No. } & \multirow{2}{*}{ Occupation } & \multicolumn{2}{|c|}{ No. of Patients } & \multirow{2}{*}{$\begin{array}{c}\text { Total No. of } \\
\text { Patients }\end{array}$} & \multirow{2}{*}{$\%$} \\
\cline { 2 - 5 } & & Group A & Group B & 19 & $63.33 \%$ \\
\hline 1 & Housewife & 12 & 7 & 2 & $6.67 \%$ \\
\hline 2 & Service & 1 & 1 & 2 & $6.67 \%$ \\
\hline 3 & Business & - & 2 & 2 & $6.67 \%$ \\
\hline 4 & Retired & - & 2 & 5 & $16.67 \%$ \\
\hline 5 & Labor & 2 & 3 & $\mathbf{3 0}$ & $\mathbf{1 0 0}$ \\
\hline
\end{tabular}


Table 3: Distribution of 30 Patients according To Vikrita Dosha

\begin{tabular}{|c|l|c|c|c|c|}
\hline \multirow{2}{*}{ S. No. } & \multirow{2}{*}{ Vikrita Dosha } & \multicolumn{2}{|c|}{ No. of Patients } & \multirow{2}{*}{$\begin{array}{c}\text { Total No. of } \\
\text { Patients }\end{array}$} & \multirow{2}{*}{$\%$} \\
\cline { 3 - 4 } & & Group A & Group B & 15 & $50.0 \%$ \\
\hline 1 & Vataja & 5 & 10 & 0 & - \\
\hline 2 & Pittaja & 0 & 0 & 0 & - \\
\hline 3 & Kaphaja & 0 & 0 & 0 & - \\
\hline 4 & Vata Pittaja & 0 & 0 & 0 & - \\
\hline 5 & Pitta Kaphaja & 0 & 0 & 15 & $50.0 \%$ \\
\hline 6 & Vata Kaphaja & 10 & 5 & $\mathbf{3 0}$ & $\mathbf{1 0 0}$ \\
\hline & Total & $\mathbf{1 5}$ & $\mathbf{1 5}$ & \\
\hline
\end{tabular}

Table 4: Distribution of 30 Patients according to Pramana

\begin{tabular}{|c|l|c|c|c|c|}
\hline \multirow{2}{*}{ S.No. } & \multirow{2}{*}{ Pramana } & \multicolumn{2}{|c|}{ No. of Patients } & \multirow{2}{*}{$\begin{array}{c}\text { Total No. of } \\
\text { Patients }\end{array}$} & \multirow{2}{*}{$\%$} \\
\cline { 2 - 5 } & & Group A & Group B & 15 & $50.00 \%$ \\
\hline 1 & Sthul & 8 & 7 & 11 & $36.67 \%$ \\
\hline 2 & Madhyama & 6 & 5 & 4 & $13.33 \%$ \\
\hline 3 & Krush & 1 & 3 & $\mathbf{3 0}$ & $\mathbf{1 0 0}$ \\
\hline & Total & $\mathbf{1 5}$ & $\mathbf{1 5}$ & \\
\hline
\end{tabular}

Table 5: Distribution of 30 Patients according to Course of the Disease

\begin{tabular}{|c|c|c|c|c|c|}
\hline \multirow{2}{*}{ S. No. } & \multirow{2}{*}{ Incidence of Course } & \multicolumn{2}{|c|}{ No. of Patients } & \multirow{2}{*}{$\begin{array}{l}\text { Total No. of } \\
\text { Patients }\end{array}$} & \multirow{2}{*}{$\%$} \\
\hline & & Group A & Group B & & \\
\hline 1 & Progressive & 15 & 15 & 30 & $100 \%$ \\
\hline 2 & Relapsing & 0 & 0 & 0 & - \\
\hline 3 & Stationary & 0 & 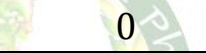 & 0 & - \\
\hline & Total & 15 & 15 & 30 & $100 \%$ \\
\hline
\end{tabular}

Table 6: Distribution of 30 Patients according To Symptoms

\begin{tabular}{|c|l|c|c|c|c|}
\hline \multirow{2}{*}{ S.No. } & \multirow{2}{*}{ Symptoms } & \multicolumn{2}{|c|}{ No. of Patients } & \multirow{2}{*}{$\begin{array}{c}\text { Total No. of } \\
\text { Patients }\end{array}$} & \multirow{2}{*}{$\%$} \\
\cline { 3 - 4 } & & Group A & Group B & 30 & $100 \%$ \\
\hline 1 & Sandhi Shula & 15 & 15 & 27 & $90 \%$ \\
\hline 2 & Sandhi Shotha & 15 & 12 & 25 & $83.33 \%$ \\
\hline 3 & Tenderness & 15 & 10 & 13 & $43.33 \%$ \\
\hline 4 & Vata Purna Druti Sparsha & 11 & 2 & 29 & $96.67 \%$ \\
\hline 5 & $\begin{array}{l}\text { Akunchana Prasaranajanya } \\
\text { Vedana }\end{array}$ & 15 & 14 & 27 & $90.00 \%$ \\
\hline 6 & Sandhigraha & 15 & 12 & 29 & $96.67 \%$ \\
\hline 7 & Sandhi Sphutana & 15 & 14 & & \multirow{2}{*}{ S } \\
\hline
\end{tabular}

Table 7: Distribution of 30 Patients according To Joint Involvement

\begin{tabular}{|c|l|c|c|c|c|}
\hline \multirow{2}{*}{ S. No. } & \multirow{2}{*}{ Joint Involvement } & \multicolumn{2}{|c|}{ No. of Patients } & \multirow{2}{*}{ Total } & \multirow{2}{*}{$\%$} \\
\cline { 3 - 4 } & & Group A & Group B & & \\
\hline 1 & Unilateral & 2 & 3 & 5 & $16.67 \%$ \\
\hline 2 & Bilateral & 13 & 12 & 25 & $83.33 \%$ \\
\hline & Total & $\mathbf{1 5}$ & $\mathbf{1 5}$ & $\mathbf{3 0}$ & $\mathbf{1 0 0 \%}$ \\
\hline
\end{tabular}

Table 8: Distribution of 30 Patients according to O.A changes as seen in X-ray

\begin{tabular}{|c|l|c|c|c|c|}
\hline \multirow{2}{*}{ S. No. } & \multirow{2}{*}{ O.A changes as seen in X-ray } & \multicolumn{2}{|c|}{ No. of Patients } & \multirow{2}{*}{ Total } & \multirow{2}{*}{$\%$} \\
\cline { 3 - 4 } & & Group A & Group B & & \\
\hline 1 & Early (mild) O.A. changes & 3 & 5 & 8 & $26.67 \%$ \\
\hline 2 & Moderate O.A. changes & 6 & 8 & 14 & $46.67 \%$ \\
\hline 3 & Severe O.A. changes & 6 & 2 & 8 & $26.67 \%$ \\
\hline & Total & $\mathbf{1 5}$ & $\mathbf{1 5}$ & $\mathbf{3 0}$ & $\mathbf{1 0 0 \%}$ \\
\hline
\end{tabular}


Int. J. Ayur. Pharma Research, 2022;10(1):14-20

Table 9: Distribution of 30 Patients according To Knee X-ray Findings

\begin{tabular}{|c|l|c|c|c|c|}
\hline \multirow{2}{*}{ S. No. } & \multirow{2}{*}{ Knee X-ray Examination } & \multicolumn{2}{|c|}{ No. of Patients } & \multirow{2}{*}{ Total } & \multirow{2}{*}{$\%$} \\
\cline { 2 - 4 } & Group A & Group B & \\
\hline 1 & $\begin{array}{l}\text { Only medial compartment of TF joint } \\
\text { involvement }\end{array}$ & 8 & 11 & 19 & $63.33 \%$ \\
\hline 2 & $\begin{array}{l}\text { Medial \& lateral (both) compartment of TF } \\
\text { joint involvement }\end{array}$ & 7 & 4 & 11 & $36.67 \%$ \\
\hline 3 & Both TF and PF joint involvement & 5 & 4 & 9 & $30.00 \%$ \\
\hline 4 & Osteophytes & 14 & 10 & 24 & $80.00 \%$ \\
\hline 5 & Loose bodies & 5 & 3 & 8 & $26.67 \%$ \\
\hline 6 & Osteoporosis & 2 & 0 & 2 & $6.67 \%$ \\
\hline
\end{tabular}

(TF= Tibio-femoral, $\mathrm{PF}=$ Patello-femoral)

Table 10: Effect of Therapy in Subjective Parameters. (Paired t- test)

\begin{tabular}{|c|c|c|c|c|c|c|c|c|c|c|}
\hline \multirow{2}{*}{ Variable } & \multirow{2}{*}{ Group } & \multicolumn{2}{|c|}{ Mean } & \multirow{2}{*}{$\begin{array}{l}\text { Mean } \\
\text { Diff. }\end{array}$} & \multirow{2}{*}{$\begin{array}{c}\text { \% } \\
\text { Relief }\end{array}$} & \multirow{2}{*}{ SD \pm} & \multirow{2}{*}{ SE \pm} & \multirow{2}{*}{$\mathbf{T}$} & \multirow{2}{*}{$\mathbf{P}$} & \multirow{2}{*}{$\mathbf{S}$} \\
\hline & & BT & AT & & & & & & & \\
\hline \multirow[t]{2}{*}{ Sandhi Shula } & A & 3.40 & 1.40 & 2 & 58.22 & 0.845 & 0.218 & 9.165 & $<0.001$ & $\mathrm{HS}$ \\
\hline & B & 3.87 & 2.13 & 1.67 & 42.67 & 0.703 & 0.181 & 9.539 & $<0.001$ & $\mathrm{HS}$ \\
\hline \multirow{2}{*}{ Sandhi Shotha } & A & 2.60 & 0.87 & 1.73 & 72.22 & 0.703 & 0.181 & 9.539 & $<0.001$ & $\mathrm{HS}$ \\
\hline & $\mathrm{B}$ & 1.60 & 1.07 & 0.67 & 33.64 & 0.743 & 0.191 & 2.779 & 0.015 & $\mathrm{~S}$ \\
\hline \multirow{2}{*}{ Tenderness } & A & 2.40 & 0.73 & 1.67 & 70.11 & 0.816 & 0.210 & 7.906 & $<0.001$ & $\mathrm{HS}$ \\
\hline & $\mathrm{B}$ & 1.20 & 0.67 & 0.53 & 30.00 & 0.639 & 0.165 & 3.228 & 0.006 & $\mathrm{~S}$ \\
\hline \multirow{2}{*}{$\begin{array}{l}\text { Vata Purna Druti } \\
\text { Sparsha }\end{array}$} & A & 1.20 & 0.40 & 0.80 & 69.44 & 0.560 & 0.144 & 5.52 & $<0.001$ & $\mathrm{HS}$ \\
\hline & $\mathrm{B}$ & 0.33 & 0.13 & 0.20 & 7.78 & 0.560 & 0.144 & 1.382 & 0.189 & IS \\
\hline \multirow{2}{*}{$\begin{array}{l}\text { Akunchana } \\
\text { Prasaranajana Vedana }\end{array}$} & A & 2.60 & 0.87 & 1.73 & 65.56 & 0.798 & 0.206 & 8.404 & $<0.001$ & $\mathrm{HS}$ \\
\hline & $\mathrm{B}$ & 1.67 & 0.73 & 0.93 & 55.95 & 0.883 & 0.228 & 4.09 & $<0.001$ & $\mathrm{HS}$ \\
\hline \multirow{2}{*}{ Sandhigraha } & A & 2.47 & 0.80 & 1.67 & 64.44 & 0.899 & 0.232 & 7.17 & $<0.001$ & $\mathrm{HS}$ \\
\hline & B & 1.53 & 0.67 & 0.87 & 44.44 & 0.639 & 0.165 & 5.24 & $<0.001$ & $\mathrm{HS}$ \\
\hline \multirow{2}{*}{ Sandhi Sphutana } & A & 2.13 & 0.73 & 1.40 & 68.89 & 0.507 & 0.130 & 10.69 & $<0.001$ & $\mathrm{HS}$ \\
\hline & $\mathrm{B}$ & 1.73 & 1.13 & 0.60 & 33.33 & 0.736 & 0.190 & 3.154 & 0.007 & $\mathrm{~S}$ \\
\hline
\end{tabular}

Table 11: Overall Effect of the Treatment

\begin{tabular}{|l|c|c|c|c|}
\hline Effect of therapy & Group A & \% & Group B & \% \\
\hline Complete remission (100\%) & 0 & - & 0 & - \\
\hline Marked improvement (75-99\%) & 3 & $20.0 \%$ & 1 & $6.67 \%$ \\
\hline Moderate improvement (50-74\%) & 11 & $73.33 \%$ & 6 & $40.0 \%$ \\
\hline Mild improvement (25-49\%) & 1 & $6.67 \%$ & 7 & $46.67 \%$ \\
\hline Unimproved (0-24\%) & 0 & - & 1 & $6.67 \%$ \\
\hline
\end{tabular}

Chart 1: Improvement in symptoms of Group A \& B

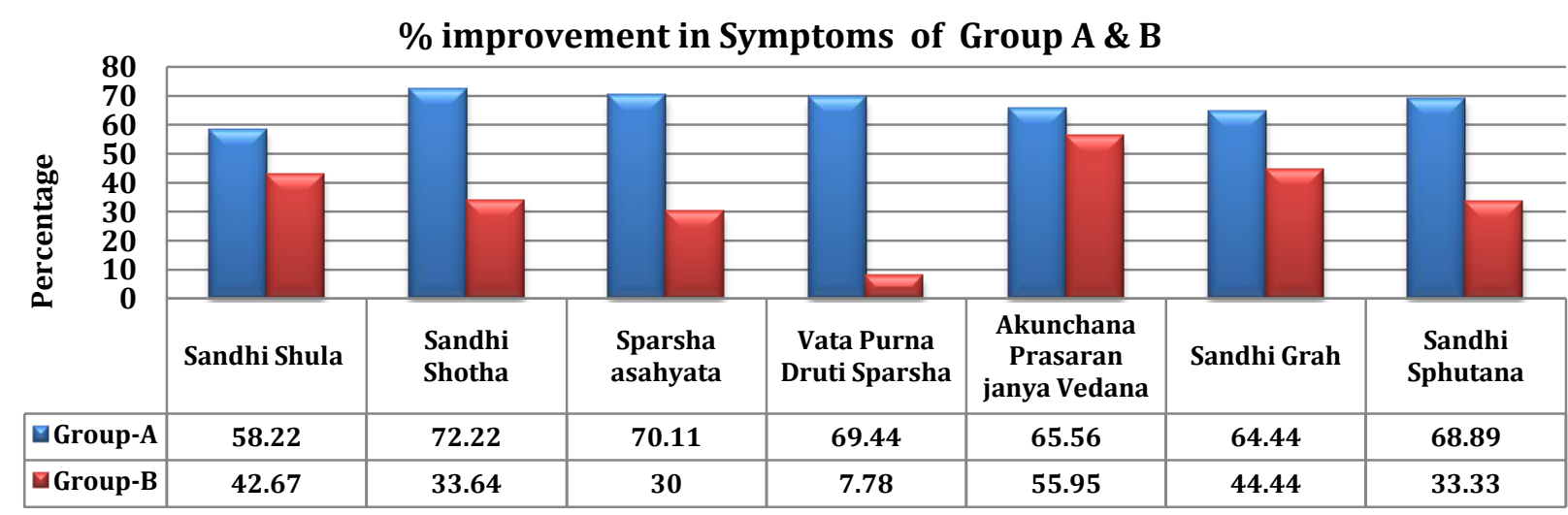




\section{Chart 2: Improvement in Symptoms of Strotodusti}

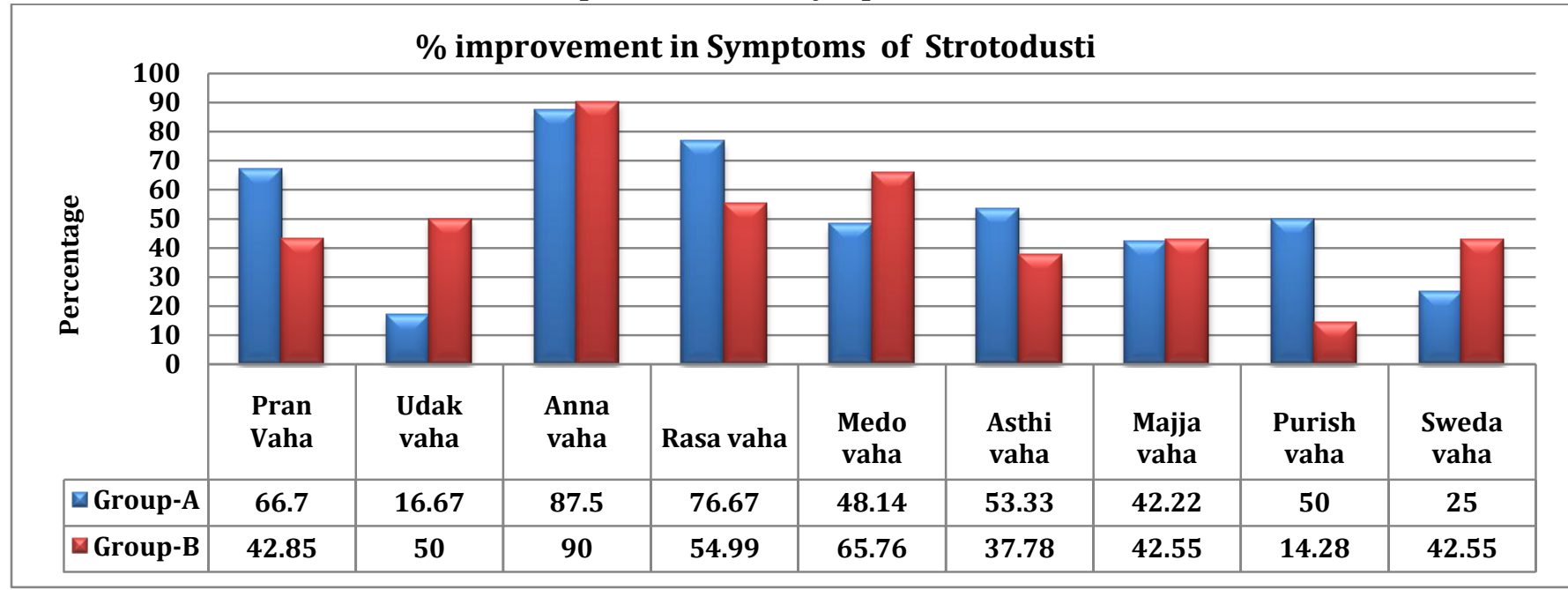

Chart 3: Overall effects of the treatment

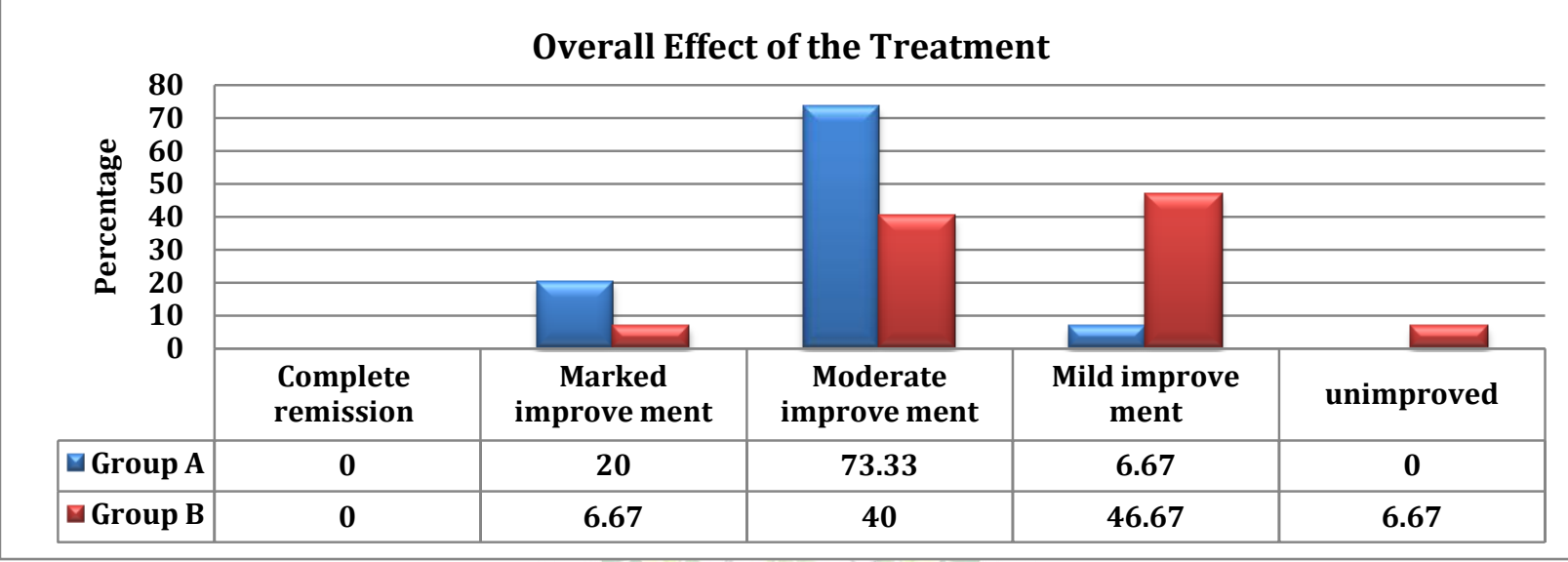

RESULT

\section{Effect of therapies}

\section{Group A: Matra Basti along with Shaman}

In this group patients were treated with Matra Basti for 15 consecutive days. Simultaneously patients were given Sahacharadi Kwath orally for 4 weeks. (Table 10) This therapy provided highly significant $(\mathrm{P}<0.001)$ result in Sandhi Shula $(58.22 \%)$, Sandhi Shotha (72.22\%), tenderness (70.11\%), Vata Purna Druti Sparsha (69.44\%), Akunchana Prasarana Janya vedana (65.56\%), Sandhigraha (64.44\%), Sandhi Sphutana $(68.89 \%)$.

\section{Group-B}

15 patients were treated only by Sahacharadi Kwath with Til Taila. (Table 10) This therapy has provided highly significant relief $(\mathrm{P}<0.001)$ in the Sandhi Shula (42.67\%), Akunchana Prasaranajanya Vedana (55.95\%), Sandhigraha (44.44\%). Significant relief $(\mathrm{P}<0.05 \%)$ was seen in the Sandhi Shotha (33.64\%), tenderness (30.0\%) and Sandhi Sphutana (33.33\%). Insignificant result was seen in Vat Purnaa Druti Sparsha (7.78\%).

\section{Overall effect of Therapies}

The (Table-11) depicts total effect of the therapy. In Group-A, In Group A, total 15 patients were treated. Out of 15 patients $20.0 \%$ patients got marked improvement, $73.33 \%$ got moderate improvement while $6.67 \%$ patients got mild improvement. No patient got complete remission. In Group B, total 15 patients were treated. Out of them $6.67 \%$ patients got marked improvement, $40.0 \%$ patients got moderate improvement and $46.67 \%$ showed mild improvement. One patient remains unimproved. No patient got complete remission.

\section{DISCUSSION}

Sandhigata Vata being a Vat Vyadhi[4] is mainly having Vata and Kapha predominance. In Samprapti of Sandhigata Vata vitiated Vata and Kapha Dosha produce symptoms like Sandhi Shula, Sandhi Shotha, Vat Purna Druti Sparsa, Akunchan Prasaran Jany Vedna, Sandhigrah and tenderness etc.

As Sandhigata Vata is considered under Vatavyadhi, Basti is the best line of treatment. The administered Basti reaches the Pakvashaya which is the place of Purishadhara Kala. Pakvashaya and Asthi are the main seats of Vata Dosha, therefore increased or decreased formation of Vata affects all the sites of Vata especially Asthi. Hence Purishadhara Kala is also considered Asthidhara kala. So it invariably nourishes the Asthi also. 


\section{Probable mode of Action of Basti}

According to Ayurveda, the Virya of ingredients used in the Basti, gets absorbed and then through circulation reaches at the side of lesion and relieves the disease. Contents of Sahchar Taila are Sahachara, GoDugdha and Til Taila. Sahachara and Til Taila both have Ushna Virya, ${ }^{[5]}$ so they help to pacify Vata as well as Kapha Dosha. Go-Dugdha having Rasayana, Jivaniya properties which helps to pacifying Jarajanya Vata Vyadhi[6]. So that we can assume that the contents of Sahachar Taila helps to pacify Shuddha Vatika as well as Avarana Janit Samprapti of Sandhigata Vata. Matra Basti was given by Sahchar Tail which is mainly Vata Shamak followed by Pitta Kapha Shamak. These properties mainly help in the correction vitiated Vata Dosha as well as Kapha Dosha. Snigdha, Guru properties by virtue of which it reaches deeper Dhatus like Asthi and Majja by penetrating through minute channels and pacify the vitiated Dosha. Sahchara and Til Taila both have Keshy property and Kesh is Mala of Asthi Dhatu[7] so we can conclude that Sahchara Tail works till Asthivaha Strotas

\section{Probable Mode of Action of Shamana Drug}

The drug used for Shaman purpose was Sahcharadi Kwath which was prepared from Kwath Vidhi mentioned by Acharaya Chakradat. Sahacharadi Kwath is mainly having Tikta Rasa followed by Madhur, Katu and Kashaya Rasa; Ushna Virya, Dominantly Katu Vipaka and Snigdha, Laghu and Guru Guna. Doshaghnata is mainly Vatakaphaghna. Vednasthapan, Keshya, Snehna, Shothaghna, Shulghna are the main Karmas of drugs used in Sahcharadi Kwath. Most of the drugs in Sahcharadi Kwath having Snigdha, Guru and Laghu Guna. Snigdha and Guru Guna having Vathara property. Due to its Laghu Guna, it acts as Medohara drug also, which helps in reducing vitiated Medodhatu and body weight. Due to Tikta, Katu, Madhur and Kashay Rasa of Sahcharadi Kwath, Vata and Kapha Dosha are brought to normalcy in general and particularly at Sandhi region. With the correction of vitiated Vata, re-arrangement of Shleshaka Kapha may be taken place and thereby improvement of symptoms is observed. Thus we can assume that the properties of Sahcharadi Kwath help to reverse the pathological changes in Sandhigatavata.

\section{Cite this article as:}

Hetal Ramani, Akanksha Sharma, Dhaval Movaliya, Sweety Ruparel. A Clinical Comparative Study on the Efficacy of Sahacharadi Kwath with and without Matra Basti in the Management of Janu Sandhigat Vata w.s.r. to Osteo Arthritis. International Journal of Ayurveda and Pharma Research. 2022;10(1):14-20.

https://doi.org/10.47070/ijapr.v10i1.2242

Source of support: Nil, Conflict of interest: None Declared
It can be concluded that Matra Basti with Shaman (Group A) with provided better results in Sthul as well as Krisha patient of Sandhigata Vata. Highly significant result was found in all symptoms of Sandhigata Vata in Group A. Sahacharadi Kwath works excellent in Sthul patient of Sandhivata (Group B). It didn't give satisfactory result in Krisha patients of Sandhivata. Highly significant result was found in Sandhi Shula, Akunchana Prasaranajanya Vedana, Sandhigraha. No adverse reaction was reported by patients during treatment. Results of this study are very encouraging but the study was conducted on a small group of patients, so a trial should be conducted on a larger sample size.

\section{REFFERENCES}

1. Vaidya Jadavaji Trikamji Acharya,Charaka SamhitaAyurveda Dipika Commentary of Chakrapanidatta, Edition reprint 2013; Chaukhamba Subharti Sansthana Varanasi, Chikitsa Sthan 28/37 pg 618.

2. Vaidya Lakshmipati Shastri, Yoga Ratnakar Utarardha with Vidyotini Hindi commentary, edited by Chaukhambha Prakashana, Varanasi, 2010Vata Vyadhi Chikitsha 30/119, pg no.714.

3. Vaidya Jadavaji Trikamji Acharya, Charaka SamhitaAyurveda Dipika Commentary of Chakrapanidatta, Edition reprint 2013; Chaukhamba Subharti Sansthana Varanasi, Chikitsa Sthan 28/144-145; 624.

4. Vaidya Jadavaji Trikamji Acharya,Charaka SamhitaAyurveda Dipika Commentary of Chakrapanidatta, Edition reprint 2013; Chaukhamba Subharti Sansthana Varanasi, Chikitsa Sthan 28/37 pg 618.

5. Dr. K C Chunekar, Edited by Dr. Gangasahay Pandey, Bhavprakasha Nighantu, Bhavmishra Commentary by Chaukhambha Bharti Academy, Varanasi, Reprint 2010, Dhanya Varga, pg no.639 \& Puspa Varga;pg-489.

6. Dr. K C Chunekar, Edited by Dr. Gangasahay Pandey, Bhavprakasha Nighantu, Bhavmishra Commentary by Chaukhambha Bharti Academy, Varanasi, Reprint 2010, Dugdha Varga; pg-742.

7. Vaidya Jadavaji Trikamji Acharya,Charaka SamhitaAyurveda Dipika Commentary of Chakrapanidatta, Edition reprint 2013; Chaukhamba Subharti Sansthana Varanasi, Chikitsa Sthana, Chapter 15/18-19, pg 515 accuracy of the content published in our Journal. IJAPR cannot accept any responsibility or liability for the articles content which are published. The views expressed in articles by our contributing authors are not necessarily those of IJAPR editor or editorial board members. 